ARTICLE

\title{
Long-term Climatic Changes in the Northeastern Baikal Region (Russia)
}

\section{Tatiana L. Ananina ${ }^{1,2^{*}}$ Alexander A. Ananin ${ }^{1,2}$}

1. Federal State Establishment "United Administration of Barguzinsky State Nature Biosphere Reserve and Zabaikalsky National Park", Russia

2. Institute of General and Experimental Biology SB RAS, Russia

\begin{tabular}{|c|c|}
\hline ARTICLE INFO & ABSTRACT \\
\hline Article history & \multirow{11}{*}{$\begin{array}{l}\text { Due to global climate change it is important to constantly monitor the } \\
\text { current climate state, observed trends and timely detection of their chang- } \\
\text { es. The change in the hydrothermal regime has to result into changes in } \\
\text { natural ecosystems. The analysis of long-term changes of mean annual } \\
\text { temperatures and annual precipitation in warm and cold seasons over } \\
1955-2017 \text { years was carried out using data of the Davsha meteorological } \\
\text { station, } 54,35^{\circ} \mathrm{N} \text {., } 109,5^{\circ} \mathrm{E} \text {. Significant warming in the Northern Baikal } \\
\text { region has been observed since } 1990 \text { and continues to the present. The } \\
\text { climate is subcontinental with cool and short summers, frosty and long } \\
\text { winters. In the last decade, there has been a shift of the beginning some } \\
\text { phenology seasons. This had an effect on the increase in the warm season } \\
\text { of the year and the duration of the frost-free period (by } 5 \text { days from the } \\
\text { long-term average date). Spring comes earlier - for } 3 \text { days, summer and } \\
\text { the last frost - for } 5 \text { days, autumn comes later - for } 2 \text { days. }\end{array}$} \\
\hline Received: 3 August 2020 & \\
\hline Accepted: 20 August 2020 & \\
\hline Published Online: 30 September 2020 & \\
\hline Keywords: & \\
\hline Temperature & \\
\hline Precipitation & \\
\hline Oceanite & \\
\hline Continentality & \\
\hline Hydro thermality & \\
\hline Phenological border & \\
\hline
\end{tabular}

Baikal

\section{Introduction}

$\mathrm{C}$ omparison of the series of average annual air temperatures in the northern, southern hemispheres and the globe shows their consistency: warming from the beginning of the 20 th century to the 40th gave way to some cooling until the midle 70ty, after which the warming continues to the present ${ }^{[1]}$. The problem of climate change and the biota response to it became one of the most discussed issues. The local climatic conditions vary with global and regional climate change ${ }^{[2,3]}$. So, monitoring of local climate change and its impact on ecosystems is of great importance ${ }^{[4,5]}$.
The change in the hydrothermal regime has to result into changes in natural ecosystems. In the Dolomites of Italy, in habitats above the forest boundary, several cold-loving species of the genus Carabus have disappeared over the past three decades. Scientists attribute this fact to the reaction of species to climate warming ${ }^{[6,7]}$.

Regular observations of the climate in the Barguzin State Nature Biosphere Reserve, (Northern Baikal) cover the period from the late thirties. The most complete data obtained from the second half of the 20th century since 1955 at the eight time meteorological Davsha station of the second category. Significant warming in the Northern Baikal region observed since 1990 and continues to the

\footnotetext{
*Corresponding Author:

Tatiana L. Ananina, Park", Russia;

Institute of General and Experimental Biology SB RAS, Russia;

Email:t.l.ananina@mail.ru
}

Federal State Establishment "United Administration of Barguzinsky State Nature Biosphere Reserve and Zabaikalsky National 
present ${ }^{[8]}$. Thus, a change in the temperature regime of the Northern Baikal region had a corrective effect on the level of abundance of epigeobiont species of the genus Carabus. In recent decades, in response to an increase in temperature, all species have observed a reaction in the form of a burst of abundance exceeding the long-term average values. Changes in the temperature regime of the northern Baikal region had a corrective effect on the abundance of epigeobiont species of the genus Carabus. In recent decades, in some species, in response to temperature increases, there was a surge in abundance exceeding the long-term average values ${ }^{[9]}$. Transformations of the seasonal timing of registration of phenological phases in the life cycles of individual bird species are real responses to long-term climatic changes ${ }^{[10,11]}$.

This paper analyzes long-term series of the mean annual temperature, the amount of annual precipitation and their combinations in the Northeastern Baikal region for the period 1955-2017. Analysis of long-term dynamics hydro thermality indexes, frost-free period duration, thermal boundaries of phenological seasons, snow cover, first and last frost are presented.

According to the authors Ed. Stonevicius and others $(2018)^{[12]}$ the continentality index most accurately reflects its local climate changes in the Northern Hemisphere. These authors claim that a statistically significant increase in continentality has only been found in Northeast Siberia. Therefore, to characterize the long-term temperature series of the Northeastern Baikal region, along with other indicators, we used index continentality and index oceanite also. Monitoring of climatic parameters was carried out on the territory of the Barguzin State Nature Biosphere Reserve. It is located on the northeastern coast of Lake Baikal (Figure 1).

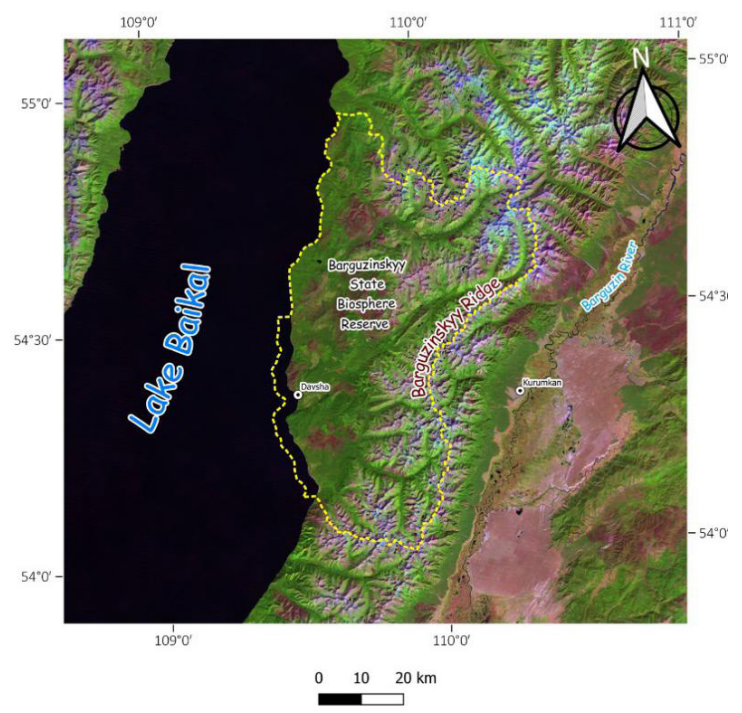

Figure 1. Location of the Barguzin State Natural Biosphere Reserve (North-Eastern coast of Lake Baikal)
The climatic conditions of the study area are determined, first of all, by its geographic location within the continent. Great influence on the climate by the proximity of Lake Baikal are lowering summer temperatures and the weakening winter frosts compared with adjacent territories ${ }^{[13]}$. The seasonal circulation of the atmosphere affects the formation of climatic conditions.

In winter, an area of high pressure is created near the surface of the earth, so the Asian (Siberian) anticyclone plays the main role (especially in January). In summer, on the contrary, the low-pressure baric field prevails; southern cyclones emerge from Mongolia into the Baikal region. Transitional autumn-spring seasons are characterized by the west-east transport of air masses. Also, in spring, cyclones from Central Asia and Kazakhstan periodically invade, in autumn meridional cold north winds break through. It is noted that autumn west-east movements are slower than spring ones ${ }^{[14]}$.

\section{Methods}

The meteorological data were taken as a basis: average monthly and annual air temperatures, -monthly and annual atmospheric precipitation. Calculated indices applied: Average annual air temperature; Duration frost-free period (DFF, biological summer); Selyaninov hydrothermal coefficient (summer period) $\left(\mathrm{HTC}_{\mathrm{s}}\right.$ ); Conrad continentality index (CCI); Kerner oceanity index (KOI). Phenological phenomena are indicative in the periodization of the annual cycle in nature. We analyzed the dates of the onset of the annual seasons.

DFF in a calendar year is the sum of days with an average daily temperature above $0{ }^{\circ} \mathrm{C}$.

HTI $_{\mathrm{S}}$ offered G.T. Selyaninov (1937) ${ }^{[15]}$, it is used to determine dry and wet years. It takes volatility caused by the air temperature. $\mathrm{HTC}_{\mathrm{S}}$ is equal to the ratio of the amount of precipitation for the period $t>10^{\circ} \mathrm{C}$ reduced by 10 :

$\mathrm{HTI}_{\mathrm{S}}=\Sigma \mathrm{P} / \Sigma \mathrm{t} * 10$,

where $\Sigma \mathrm{P}=$ the amount of precipitation for the study period, $\Sigma \mathrm{t}=$ the sum of the average daily air temperatures for the same period. This author proposes to consider the dry period during which the $\mathrm{HTI}_{\mathrm{S}}<1.0$. In Russia, for the Eastern Siberia and the Far East, favorable conditions for moisture supply are created at $\mathrm{HTI}_{\mathrm{S}}=1.3^{[15]}$.

CCI formulas proposed by Conrad ${ }^{[16]}$ and developed by Edvinas Stonevicius, 2018 and other researchers ${ }^{[12,17,18]}$. Climate continentality analyzed on the basis of the annual air temperature range ${ }^{[17,18]}$. In this research, continentality was evaluated using the equation:

$\mathrm{CCI}=1.7 *\left(\mathrm{~T}_{\max }-\mathrm{T}_{\min }\right) / \operatorname{Sin}(\varphi+10)-14$,

DOI: https://doi.org/10.30564/jasr.v3i4.2255 
where $\mathrm{T}_{\max }\left({ }^{\circ} \mathrm{C}\right)$ is the mean temperature of the warmest months of the year, $\mathrm{T}_{\min }\left({ }^{\circ} \mathrm{C}\right)$ is the mean temperature of the coldest months of the year, and $\varphi$ is the latitude.

A large annual range of air temperatures results in larger index values and consequently indicates a more continental climate. The smallest differences can be observed in the most oceanic climate conditions. The territories where index values range from $(-20)$ to 20 can be described as hyper-oceanic, from 20 to 50 as oceanic, from 50 to 60 as sub-continental, from 60 to 80 as continental, and from 80 to 120 as hyper continental ${ }^{[11]}$.

KOI represents the ratio of the mean monthly air temperature diference between October and April and the diference between mean monthly temperatures of the warmest and coldest months. Small or negative values indicate high continentality, whereas high index values indicate marine climate conditions ${ }^{[19]}$. The oceanity index (KOI) according to Kerner ${ }^{[20]}$ was evaluated as follows:

$\mathrm{KOI}=100 *\left(\mathrm{~T}_{\text {oct }}-\mathrm{T}_{\text {apr }}\right) /\left(\mathrm{T}_{\max }-\mathrm{T}_{\min }\right)$,

where $\mathrm{T}_{\text {oct }}$ and $\mathrm{T}_{\text {apr }}(\mathrm{C})$ are the mean monthly temperature in October and April, and $\mathrm{T}_{\max }$ and $\mathrm{T}_{\min }(\mathrm{C})$ are the same as in CCI.

This index is based on the assumption that in marine climates, springs are colder than autumns, whereas in continental climates, springs demonstrates higher or similar temperatures as in autumn. The oceanity of the climate increases with index values. Small or negative values demonstrate continental climate conditions, while large values indicate a marine climate ${ }^{[2]}$. In order to visualise the spatial distribution of KOI, the following classes of index were used in this research: less or equal to (-10) - hypercontinental; from (-9) to 0 - continental; from 1 to 10 - subcontinental; from 11 to 20 - oceanic; and from 21 to 50 - hyper oceanic.

The timing of the onset of the seasons was selected according to the climatic criteria of the coastal zone of the Barguzinsky Reserve, proposed by K.P. Filonov (1978) ${ }^{[22]}$. Phenological seasons boundaries:

(1) Spring is the date of the final transition of maximum air temperatures above $\mathrm{T}\left(10^{\circ} \mathrm{C}\right)$;

(2) Summer is the date of stable transition of minimum air temperatures above $\mathrm{T}\left(5^{\circ} \mathrm{C}\right)$;

(3) Autumn is the date of transition of the minimum air temperatures below $\mathrm{T}\left(0^{\circ} \mathrm{C}\right)$;

(4) Winter is the date when permanent snow cover is established.

For graphical characteristics, the time series was divided into decades. The average indicators for six decades were compared: I - 1955-1964, II - 1965-1974, III - 1975-1984, IV - 1985-1994, V - 1995-2004, VI - 2005-2017 (12 days).

Standard statistical procedures Statistica 6.0 and Excel
2000 software package ${ }^{[23]}$ to process the data set used. The contribution of trends to the long-term fluctuations of parameters was estimated by the Kendall rank correlation coefficient $\left(\mathrm{R}_{\tau} \text {, at } \mathrm{p}<0.05\right)^{[24]} . \mathrm{R}_{\tau}$ characterizes the percentage of variability of the long-term series.

\section{Results and Discussion}

Climate in the Northern Baikal region for the period 1955-2017 characterized by the following average annual indicators:

The mean annual temperature is $\left(-3.4^{\circ} \mathrm{C}\right)$ at $\min \left(-6.1^{\circ} \mathrm{C}\right)$ and $\max \left(-1.2^{\circ} \mathrm{C}\right)$. The warmest months of the year are July $\left(+12.9^{\circ} \mathrm{C}\right)$ and August $\left(+13.5^{\circ} \mathrm{C}\right)$, the coldest months are January $\left(-22.7^{\circ} \mathrm{C}\right)$ and February $\left(-21.9^{\circ} \mathrm{C}\right)$.

The mean annual precipitation is $421 \mathrm{~mm}$, with min $200 \mathrm{~mm}$ and $\max 660 \mathrm{~mm}$. A greater amount of precipitation $251 \mathrm{~mm}(60 \%)$ falls in the warm season (May-September). Precipitation in the cold half of the year is $170 \mathrm{~mm}(40 \%)$.

$\mathrm{HTI}_{\mathrm{S}}$ is 2,5 with min 0,5 and $\max 4,7$.

CCI is 56,9 with min 37,9 and $\max 70,4$.

KOI is $-10,9$ with min $-26,0$ and max 0,5 .

DFF is 117 days with min 95 days and max 140 days.

Dates of phenological events: Spring - May 24 (early May 8 and late June 14); Summer - July 4 (June 14 and July 27); Autumn - September 22 (September 7 and October 7), Winter - October 27 (October 5 and November 23). Term average last frost during the study period was June 14 (July 16 and May 19), the first frost - September 7 (August 10 and September 24. The snow cover finally established in October 27 (October 5 and November 23) and destroyed in May 6 (April 15 and May 25).

The frost-free period lasted on average 117 days (140 and 117 days).

Changes in the timing of the onset of the phenological seasons of the year are reflected in table 1 .

Table 1. The characteristic phenology phenomena in Northeastern Baikal region in 1955-2017 (average for the decades)

\begin{tabular}{|c|c|c|c|c|c|c|c|}
\hline $\begin{array}{c}\text { Phenology phe- } \\
\text { nomena, date of } \\
\text { events }\end{array}$ & $\begin{array}{c}\mathbf{1 9 5 5 -} \\
\mathbf{1 9 6 4}\end{array}$ & $\begin{array}{c}\mathbf{1 9 6 5 -} \\
\mathbf{1 9 7 4}\end{array}$ & $\begin{array}{c}\mathbf{1 9 7 5 -} \\
\mathbf{1 9 8 4}\end{array}$ & $\begin{array}{c}\mathbf{1 9 8 5 -} \\
\mathbf{1 9 9 4}\end{array}$ & $\begin{array}{c}\mathbf{1 9 9 5 -} \\
\mathbf{2 0 0 4}\end{array}$ & $\begin{array}{c}\mathbf{2 0 0 5}- \\
\mathbf{2 0 1 7}\end{array}$ & $\begin{array}{c}\mathbf{R}_{\boldsymbol{\tau}} \\
\mathbf{p}<\mathbf{0 . 0 5}\end{array}$ \\
\hline Spring & 24.05 & 28.05 & 24.05 & 24.05 & 19.05 & 21.05 & 0,2438 \\
\hline Summer & 9.07 & 8.07 & 6.07 & 2.07 & 5.07 & 29.06 & 0,3104 \\
\hline Autumn & 20.09 & 22.09 & 17.09 & 20.09 & 27.09 & 24.09 & 0,0338 \\
\hline Winter & 23.10 & 24.10 & 25.10 & 31.10 & 30.10 & 27.10 & 0,2545 \\
\hline First frost & 28.08 & 21.08 & 30.08 & 12.09 & 5.09 & 2.09 & $-0,3551$ \\
\hline Last frost & 26.06 & 15.06 & 17.06 & 11.06 & 11.06 & 9.06 & 0,4518 \\
\hline Snow setting & 23.10 & 24.10 & 25.10 & 31.10 & 30.10 & 27.10 & $-0,2545$ \\
\hline $\begin{array}{c}\text { Snow destruc- } \\
\text { tion }\end{array}$ & 26.06 & 15.06 & 17.06 & 11.06 & 11.06 & 11.06 & 0,4863 \\
\hline $\begin{array}{c}\text { Frost-free peri- } \\
\text { od (days) }\end{array}$ & 110 & 107 & 115 & 123 & 122 & 122 & 0,5386 \\
\hline
\end{tabular}


Thus, according to the analysis carried out, the climate of the Northern Baikal region can described as continental (subcontinental) with cool and short summers, frosty and long winters and above average precipitation. Precipitation is above average, most of it falls in summer. The cold period (with negative temperatures) averages $68 \%$, and the warm period takes only one third of the calendar year. However, in the last three decades, there has been a shift of the beginning of the phenological seasons of summer and winter (first and last frosts). This had an effect on the increase in the warm season of the year, and, accordingly, on the increase in the duration of the frost-free period (by 5 days from the long-term average date). In the last decade, spring comes earlier - for 3 days, summer and the last frost - for 5 days, autumn comes later - for 2 days. The winter in the last decade comes exactly on the average long-term date, without changing, table 1 .

The evolution of the mean annual temperature of the long-term series shown in Figure 2.

A
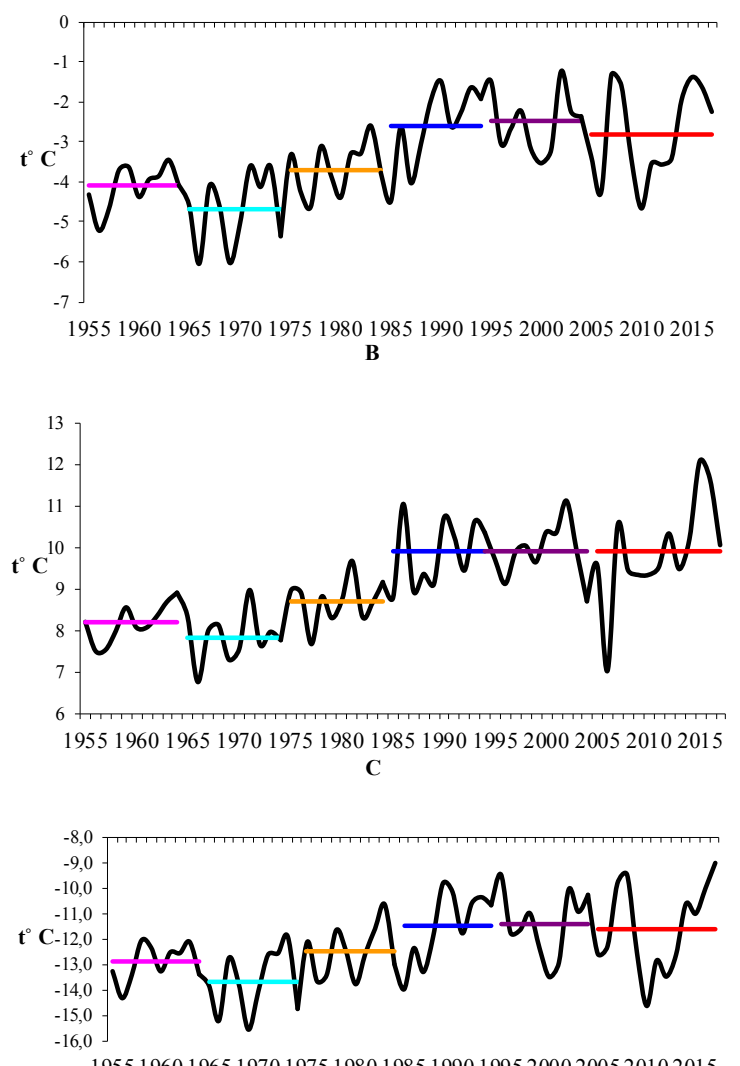

1955196019651970197519801985199019952000200520102015

\begin{tabular}{|c|c|c|}
\hline$\longrightarrow$ 1955-1964 & $-1965-1974$ & 1975-1984 \\
\hline -1985-1994 & $\longrightarrow$ 1995-2004 & $\longrightarrow 2005-2017$ \\
\hline
\end{tabular}

Figure 2. Dynamics of the average temperature for decades in the Northern Baikal region, A - average, B - warm season (May-September), C - cold season (October-April)
The contribution of the linear trend of the average annual temperature is $R_{\tau}=0,4173$, in the warm season $-R_{\tau}=$ 0,7060 , in the cold season $-R_{\tau}=0,5037$. The amplitude of fluctuations in the mean annual air temperature is $6.5^{\circ} \mathrm{C}$. The linear trend of the mean annual air temperature is positive (correlation coefficient Tau $=0.421$ ). The average long-term values in the previous periods of research: in 1955-1976. - $\left(-4.1^{\circ} \mathrm{C}\right), 1955-1998-\left(-3.7^{\circ} \mathrm{C}\right), 1955-$ 2007. $-\left(-3.1^{\circ} \mathrm{C}\right)^{[25]}, 2000-2017-\left(-2.8^{\circ} \mathrm{C}\right), 1955-2015$ - $\left(-3.4^{\circ} \mathrm{C}\right)$. The average temperature for each of the 6 decades was higher in the fifth $\left(-2.5^{\circ} \mathrm{C}\right)$, maximum - $(+$ $\left.0.4^{\circ} \mathrm{C}\right)$ in 2004 , lower - in the second decade $\left(-4.7^{\circ} \mathrm{C}\right)$, minimum $-\left(-6.1^{\circ} \mathrm{C}\right)$ in 1966 , and $\left(-6.0^{\circ} \mathrm{C}\right)$ in 1969 . A significant increase in air temperature was noted from the third decade $\left(-3.7^{\circ} \mathrm{C}\right)$, the maximum $\left(-2.6^{\circ} \mathrm{C}\right)$ in 1983. Since the fourth decade, the average annual temperature has remained constantly high $\left(-2.6^{\circ} \mathrm{C}\right)$, the maximum temperature for the last three decades was $\left(-1.2^{\circ} \mathrm{C}\right)$ in 2002 (Figure $2 \mathrm{~A}$ ).

The evolution of the total annual precipitation and $\mathrm{HTI}_{\mathrm{S}}$ shown in Figure 3

A
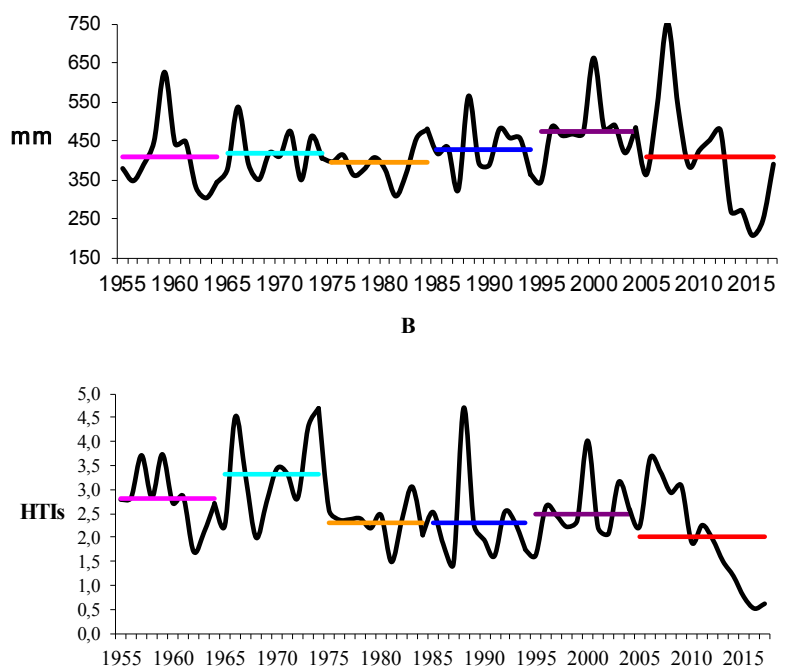

\begin{tabular}{|lll|}
\hline $1955-1964$ & $1965-1974$ & 1975-1984 \\
1985-1994 & $-1995-2004$ & $-2005-2017$ \\
\hline
\end{tabular}

Figure 3. Dynamics of the total precipitation (A) and the Hydrothermal Index (B) for decades in the Northern Baikal region

The deviation of the amount of precipitation $\left(\mathrm{R}_{\tau}\right.$ $=0,0472)$ and, accordingly $\operatorname{HTI}_{\mathrm{S}}\left(\mathrm{R}_{\tau}=0,0892\right)$, in the dynamic series from the average long-term value was absolutely insignificant, except for the last decade $\mathrm{R}_{\tau}=$ 0,3934 and $R_{\tau}=0,4123$. It is characteristic that in the sixth decade the largest amount of precipitation observed $750.2 \mathrm{~mm}$, in 2007 and the smallest $-205.9 \mathrm{~mm}$, in 2015 . 
(Figure 3, A). A significant decrease in $\mathrm{HTI}_{\mathrm{S}}$ noted since 2012, which contributed to a sharp increase in climate aridity (Figure 3, B) and fire hazard. This reflected in the frequency of forest fires in 2013, 2015, 2016 not only on the territory of the reserve, but throughout the entire Baikal region.

The dynamics of the indices of oceanicity and continentality shown in Figure 4.

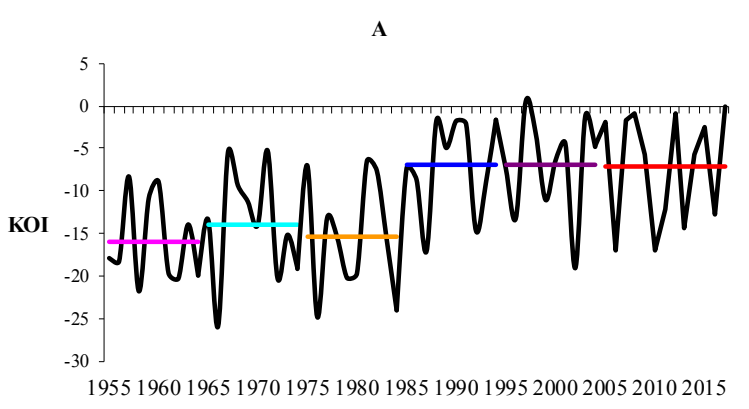

B

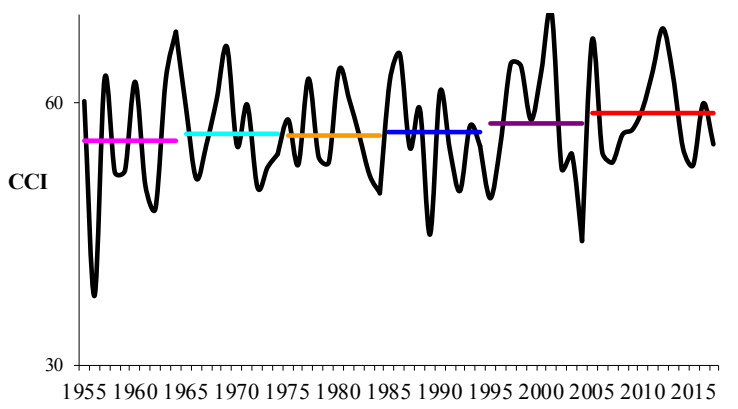

Figure 4. Dynamics of indexes KOI (A) and CCI (B) for decades

The dynamics of the CCI did not differ in large changes $\left(R_{\tau}=0,1427\right)$ and the linear trend almost did not go beyond the stationary one $\left(R^{2}=0204\right)$. On the contrary, the oceanic index $\left(\mathrm{R}_{\tau}=0,4959\right)$ and linear trend $\left(\mathrm{R}^{2}=\right.$ $0,2459)$ showed a significant decrease in the continentality of the climate over the past three decades since 1988 in the Northern Baikal region.

\section{Conclusion}

Over the past 62 years, significant climate change has been marked on Northern Baikal. The duration of the frost-free period increased due to the shift in the dates of the phenology borders beginning of spring, summer and autumn. With an increase in air temperature and with the same level of precipitation, the oceanity/continentality of the climate decreased significantly. A significant decrease in hydrothermal index noted since the beginning of the second millennium, which contributed to a sharp increase in climate aridity.

\section{References}

[1] Sokolov, L. V. Climate in the life of plants and animals. Saint Petersburg: Publishing house Tessa, 2010: 343.

[2] Nazimova, D. I., Tsaregorodtsev, V. G., Andreyeva, N. M. Forest vegetation zones of Southern Siberia and current climate change, Geography and Natural Resources, 2010, 31(2): 124-131.

[3] Luff, M. L. The carabidae (ground beetles) of Britain and Ireland. RES Handbook. Field Studies Council, Shrews-bury, 2007, 4(2): 247.

[4] Ananina, T.L., Ananin, A.A. Some results of monitoring the temperature regim in the altitude zone of the Barguzin Ridge (Northen Baikal region). Material of the International Conference (Birmingham, United Kingdom, 2019: 113-121.

DOI 10.34660/INF.2019.1.41068

[5] Pospelova, E. B., 1, Pospelov I. N., Orlov, M.V. Climate change in Eastern Taimyr over the last 80 years and the warming impact on biodiversity and ecosystem processes in its territory. Nature Conservation Research, 2017, 2(3): 215-221.

DOI: $10.24189 /$ ncr.2017.040

[6] Ananin, A.A., Ananina, T.L., Darizhapov, E.A., Puzachenko, A.Yu., Fadeev, A.S. The influence of climate change on the biota of the Barguzin reserve. The influence of climate change on ecosystems. M .: Russian University, 2001, 2: 1-8.

[7] Brandmayer, P., Pizzalotto, R. Climate change and its impact on epigean and hypogean carabid beetles. Periodicum Biologorum, 2016, 118(3): 147-162.

DOI: $10.18054 / \mathrm{pb} .2016 .118 .3 .4062$

[8] Ananina, T.L., Ananin, A.A. Some results of temperature monitoring obtained using automatic meteorological instruments (Barguzinsky ridge). Natural complexes of the North-Eastern Baikal region. Proceedings of the Barguzinsky state natural biosphere reserve. FSE United Administration of Barguzinsky State Nature Biosphere Reserve and Zabaikalsky National Parc. Ulan-Ude: Publishing House of Buryat Scientific Center of the Siberian Branch of the Russian Academy of Sciences, 2019, 11: 183-189. DOI: $10.31554 / 978-5-7925-9-11-2019-183-189$

[9] Ananina, T.L. Results of longterm monitoring of the genus Carabus (Coleoptera: Carabidae) in the Barguzinsky range (Northern Baikal Region). Contemporary Problems of Ecology, 2020, 4: 491-503.

DOI: $10.15372 /$ SEJ20200407

[10] Ananin, A. A. Formation and analysis of long-term series of bird population observations at key sites as a method of studying biodiversity. Contemporary 
Problems of Ecology, 2020, 4: 479-490. DOI: 10.15372/SEJ20200406

[11] Lehikoinen, A., Lindén, A., Karlsson, M., Andersson, A., Crewe, T. L., Dunn, E. H., Gregory, G., Karlsson, L., Kristiansen, V., Mackenzie, S., Newman, S., Røer, J. E., Sharpe, C., Sokolov, L. V., Steinholtz, Å., Stervander, M., Tirri, I. S., Tjørnløv, R. S. Phenology of the avian spring migratory passage in Europe and North America: Asymmetric advancement in time and in-crease in duration. Ecol. Indicat., 2019, 101: 985-991.

[12] Stonevicius Ed., Stankunavicius G., Rimkus, Eg. Continentality and Oceanity in the Mid and High Latitudes of the Northern Hemisphere and Their Links to Atmospheric Circulation. Advances in Meteorology, Article ID, 5746191, 2018: 12. DOI: doi.org/10.1155/2018/5746191

[13] Ladokhin, N.P., Turcan, A. M. An outline of the local climate of the coastal zone of the Barguzinsky reserve. Proceedings of the Barguzinsky state reserve. Moscow, 1948, 1: 149-176.

[14] Ecological atlas of the Baikal basin. Irkutsk: Publishing house of the Institute of Geography. B. B. Sochava SO RAN, 2015, 145.

[15] Selyaninov, G.T. Methodology for agricultural characteristics of the climate. World Agroclimatic Directory. Leningrad-Moscow, 1937: 5-26.

[16] Conrad, V. Usual formulas of continentality and their limits of validity. Proceedings of the American Geophysical Union, 1946, 27(5): 663-664.

[17] Vil`cek, J., 'Skvarenina, J., Vido, J., Nalevankov'a, P., Kandr' 'k, R., 'Skvareninov'a, J. (2016). Minimal change of thermal continentality in Slovakia within the period 1961-2013. EarthSystem Dynamics, 1946, 7(3): 735-744.

[18] Gadiwala, S.M., Burke, F., T. Alam, M., Nawazul-Huda, S., Azam, M. Oceanity and continentality climate indices in Pakistan. Malaysian Journal of Society and Space, 2013, 9(4): 57-66.

[19] Kerner, F. Thermoisodromen, Versuch einer kartographischen Darstellung des jahrlichen Ganges der Lufttemperatur (Wien). K. K. Geographische Gesellschaft, 1905, 6(3): 30.

[20] Andrade, C., Corte-Real, J. Assessment of the spatial distribution of continental-oceanic climate indices in the Iberian Peninsula. International Journal of Climatology, 2017, 37(1): 36-45.

[21] Hirschi, J. M., Sinha, B., Josey, S. A. Global warming and changes of continentality since 1948 . Weather, 2007, 62(8): 215-221.

[22] Filonov, K.P. Seasonal development of nature in the Barguzinsky reserve. Natural complex of the Northeastern Baikal region. Proceedings of the Barguzinsky State Reserve. Ulan-Ude, 1978, 7: 47-67.

[23] Tyurin, Yu.N., Makarov, A.A. Statistical analysis of data on a computer/ed. V.E. Figurnova. M .: INFRA-M, 1978, 528.

[24] Pesenko, Yu.A. Principles and methods of quantitative analysis in faunistic research. M.: Nauka, 1982, 287.

[25] Ananina, T.L. Temperature factor in the life of the dominant species of ground beetles (Coleoptera, Carabidae) of the Barguzinsky ridge. Bulletin of the Samara Scientific Center of the Russian Academy of Sciences, 2010, 12(33), 1(5): 1260-1263. 